\title{
On our watch
}

\section{Rebecca Coombes head of investigations and features}

The BMJ

"Doctors can always do harm, even — and especially—when well intentioned," writes our GP columnist Margaret McCartney this week, with typical frankness (doi:10.1136/bmj.h5830). Her subject is female genital mutilation and a new law in England and Wales that directs doctors, among others, to report signs of any cases in children to the police. Invading "the land behind the consulting room door" is a mistake because there "the ground is fragile," she says. "The space is precious." And patients' "freedom to speak is permissible often only because of an implicit assurance of privacy."

It's a point that could be equally directed at this week's debate topic (doi:10.1136/bmj.h6148): should GPs be paid to reduce unnecessary referrals? But this time it's money, and not the law, that threatens patients' trust. Some English clinical commissioning groups are offering up to $£ 11000$ ( $€ 16000 ; \$ 17$ 000) per practice to refer fewer patients for specialist consultations, scans, and operations. On one side of the debate Peter Melton, who works for a clinical commissioning group, says that with proper safeguards such incentives improve patient care. But the academic ethicist David Shaw is not so sure.

Cutting referrals risks missing important cases, especially early cancer. "Are doctors really telling patients that they are receiving incentives for not referring them?" he asks. "Patients are bound to lose trust."

Paris will not halt its global climate change talks next week. But will world leaders gathering in this grieving city agree a strategy for a rapid "transition to a low carbon world," asks Robin Stott and a powerful new alliance of UK health leaders (doi:10.1136/bmj.h6178). Their strong words are part of a push to raise the profile of health in the negotiations. "Climate change is happening on our watch," they warn. But at home there is only a depressing rollback on promises, while air pollution in UK cities is "exhausting the best efforts of the NHS."

Also happening on "our watch" is the next global outbreak of infectious disease. Allen Ross, professor of tropical medicine and global health, describes a deadly timeline from severe acute respiratory syndrome (SARS) in 2003 through to Ebola virus disease in 2014 (doi:10.1136/bmj.h6156). It drives home the likelihood that within the next five years a virus from the tropics may cause a pandemic, he says. But poorer countries cannot cope and contain a pandemic, he adds, so "instead of allocating huge resources to react to pandemics, funds must be earmarked to prevent them."

What can we learn from previous outbreaks? A Swedish study provides more evidence that vaccination against swine flu is safe in pregnancy (doi:10.1136/bmj.h5585). And Chinese researchers (doi:10.1136/bmj.h5765) consider the unusual case of nosocomial patient to patient transmission of avian influenza A this year.

Cite this as: BMJ 2015;351:h6221

๑ $\odot$ BMJ Publishing Group Ltd 2015 